Article

\title{
No Money? No Problem! The Value of Sustainability: Social Capital Drives the Relationship among Customer Identification and Citizenship Behavior in Sharing Economy
}

\author{
Yu-Bing Wang (i) and Ching-Wei Ho \\ Department of Marketing, Feng Chia University, Taichung 40724, Taiwan; ybwang@mail.fcu.edu.tw (Y.-B.W.); \\ chingwei1121@yahoo.com.tw (C.-W.H.); Tel.: +886-4-2451-7250 (ext. 4390) (Y.-B.W)
}

Received: 19 July 2017; Accepted: 4 August 2017; Published: 8 August 2017

\begin{abstract}
This work provides a novel approach to the corporate social responsibility (CSR) concept and to CSR activities, using social capital as the driver of consumer citizenship behavior in the sharing economy business system. An online consumer questionnaire was carried out in Taiwan to examine seven proposed hypotheses to investigate the factors affecting behavior intention. The sample includes 445 participants and investigated their consumer citizenship behavior in response to companies' participation in CSR activities and sharing of economic opportunities, in this case, Airbnb Inc. This study uses structural equation modeling (SEM) to analyze the data. The result explores a new form of entrepreneurship marketing strategy and indicates that CSR has a positive effect on consumer-company $(\mathrm{C}-\mathrm{C})$ identification and the perceived value of sustainability. This study also establishes that social capital is the key mediator of the relationship between $\mathrm{C}-\mathrm{C}$ identification and the perceived value of sustainability in consumer citizenship behavior. This research contributes to the idea that marketers should build well-designed CSR activities and deliver the perceived value of sustainability and consumer identification through social capital accumulation, which has proven to positively increase consumer citizenship behavior in the sharing economy environment. Consequently, the authors can suggest that entrepreneurs/executives should understand that CSR affects the perception of sustainability, consumer-company identification and improve consumer citizenship behavior. Most importantly, CSR activities focusing on sustainability issues and operating with social capital may lower costs and improve efficiencies as well. This finding could be viewed as a pioneering benchmark for further research.
\end{abstract}

Keywords: corporate social responsibility; sharing economy; sustainability; social capital; consumercompany identification; consumer citizenship behavior; Airbnb Inc.

\section{Introduction}

Background

The sharing economy is an emerging social and technological phenomenon based on developments in information and communications technology (ICT) that implies the collaborative consumption of physical, virtual, and intellectual goods. Booms in Internet technology and mobile online services have psychologically, sociologically, environmentally, and economically altered consumer purchase behaviors. The sharing economy is a new model of consumer-company relationship that combines the concepts of social movement and eco-friendliness, and relies on social networks and mobile technology. The combination of the sharing economy with collaborative consumption is a new economic model and business system beyond traditional production in both 
consumption psychology and behavior. PriceWaterhouseCoopers $(\mathrm{PwC})$ defined the sharing economy as the allowing of individuals and groups to make money from underused assets. This can be categorized into hospitality, automotive, consumer goods, and even knowledge sharing. Sharing economy revenues are expected to grow at around $35 \%$ per year. The five key sharing sectors, including travel, car sharing, finance, music, video streaming, and even staffing have the potential to increase to $\$ 335$ billion by 2025. Furthermore, $76 \%$ of consumers in this research agree that the sharing economy is better for the environment. This means that for companies still toeing the line on corporate social responsibility (CSR), the sharing economy concept can be a wake-up call.

The rise of the sharing economy is predicted to have a major societal impact, and thus has relevance to both practitioners and policy makers. This study investigates the power of this emerging trend and the behavior intention of the sharing economy and CSR. The sharing economy has now garnered the attention of government officials, researchers, and service providers of online platforms, bringing many reports and much information into availability through research papers, magazines, and newspaper articles relating to the sharing economy. However, authors found a general lack of operational details and suggestions in these publications, specifically marketing strategies and branding design for more powerful consumer intent. The emergence of a new economic model with a CSR concept needs to be studied regarding the motivational factors on consumer perception value of sustainability, consumer-company $(\mathrm{C}-\mathrm{C})$ identification, and social currency toward consumer citizenship intentions in the sharing economy business model.

CSR is a crucial concept in the academic world and is becoming a more pressing item for practical corporate agendas. Studies have argued that a socially responsible corporation should strive to make a profit, obey the law, be ethical, and be a good corporate citizen [1-4]. Moreover, a great number of scholars have suggested that companies can derive enormous benefits when they are perceived as being socially responsible by their stakeholders [5,6]. Of all of a company's stakeholders, consumers are particularly susceptible to a company's CSR $[7,8]$. Previous academic research efforts have demonstrated that CSR has a positive influence on consumer evaluations and purchase intentions [9-12]. CSR allows consumers to identify with a particular company [13], specifically through the concept of C-C identification as suggested by [14]. Hence, when consumers recognize that a company's CSR belief has certain traits that overlap their own self-concepts, they develop a greater identification with that specific company and are more likely to support it $[10,15]$. Researchers have also found that consumer product evaluations and judgments of product attributes are influenced by a company's CSR [16,17].

Dr. Black, the founder of Managing Direct and a globally recognized CSR and sustainability expert, has said that sharing economy services such as Airbnb and Uber have strong CSR potential, particularly in terms of environmental impact. "The sharing economy as a concept is very attractive from the perspective of corporate social responsibility and sustainability", Dr. Black said. Although there are different models within the sharing economy, she still believed that they have same promise of reducing environmental impact through reliance on technology and a focus on sharing, reusing, and recycling. She also mentioned that there is the promise of increased social capital in communities and societies as a result of this, and people learn to trust complete strangers through the level of transparency and the reliability of the technology platforms in the social economy. Thus there is a lot of promise with these business models of something that really is very sympathetic to the values and the perceptions of CSR and sustainability [18].

In addition, researchers believe that consumer evaluations of a company are based on behavioral intentions, such as consumer citizenship behavior. This empirical study explores a research framework of consumer citizenship behavior in the CSR environment and the sharing economy trend. This study will reveal specific information for how CSR can operate under the context of the sharing economy. First, the authors will develop a theoretical framework that describes how companies participating in CSR can affect $\mathrm{C}-\mathrm{C}$ identification and perceived sustainability to influence consumer citizenship behavior and how those behaviors are further influenced by social capital. Second, the study uses structural 
equation modeling (SEM) as the methodology to test the model and hypotheses. Finally, the paper concludes with a discussion of marketing significance, the theoretical and practical implications, and limitations for future research. In this research, the authors advance and defend two major contentions. First, in the context of the sharing economy, investing in CSR can positively increase environmental performance (perceived value of sustainability and $\mathrm{C}-\mathrm{C}$ identification) and business performance (customer citizenship behavior). Second, examining social capital, it emerges as a moderator for customer citizenship behavior.

\section{Literature and Development of the Hypotheses}

The sharing economy business model and technology have changed the way people consume. The main purpose of this research is to ascertain a manageable marketing strategy and reveal how companies can positively affect consumer citizenship behavior by utilizing CSR in the sharing economy business system and to provide a novel approach to entrepreneurial sustainability strategies as a driver to attract consumers to participate in the sharing economy. The case for this research is the hospitality sharing economy company Airbnb Inc. (Airbnb)—a provider of travel accommodation and a pioneer of the sharing economy. With Airbnb having served over 50 million guests since it was founded in 2008, and which is now active in 191 countries and expected by many to file for an IPO, is now worth some $\$ 31$ billion after raising $\$ 3.4$ billion in funding [19]. In addition to travel accommodation, Airbnb also offers the "experiences" service. Currently, about 10\% of the Airbnb experiences available are called "social impact experiences" and are run by local non-profits that collect $100 \%$ of Airbnb's fee from each transaction [20].

Using the case company's experience, the authors hypothesize that the greater the commitment of a company toward respecting consumer rights and interests and the greater the commitment by a company to respect and protect the natural environment (CSR), the greater the level of C-C identification will be and the more the consumer will perceive the sustainability of its product/service as accumulating more social capital. Finally, the authors believe this will also increase consumer citizenship behavior.

\subsection{Corporate Social Responsibility}

A growing amount of research has attempted to define what it means for a company to be socially responsible, and numerous definitions of CSR have been adopted. The most often cited definition of CSR comes from [21], which designed a four-part conceptual model that includes economic, legal, ethical, and philanthropic responsibilities. One study mentioned that a major topic for business has been whether a corporation should be concerned with issues other than profitability [11]. The author of [22] is the co-founder of SustainailbityCXO partners worldwide, which he founded in collaboration with global sustainability leadership practitioners and thinkers. He realized that true solutions to sustainability, CSR, and corporate citizenship are not found within the CSR discipline and its practitioners, but rather in the emerging domain of the sharing economy, which typically refers to enterprises where access rather than ownership becomes the key to economic growth, scale, and profits. According to another scholar [8], companies must also achieve a fundamental level of economic and legal CSR. However, the authors believe that the new sharing economy business model can be a two-way avenue to higher levels of CSR practice and ethical and philanthropic responsibilities. Ethical responsibilities encompass those standards, norms, or expectations that reflect a concern for stakeholders, for example the environment, civil rights, and many others, while philanthropic responsibilities embody those corporate actions that respond to society's expectations, including business contributions to the arts, education, or the community [21].

Based on the societal marketing concept in [23], a socially responsible company should have concerns beyond just short-term profitability. Companies should integrate social and environmental concerns into their business operations and their interactions with their stakeholders on a voluntary basis. 
CSR is divided into two dimensions: consumer CSR and environmental CSR [24]. Consumer CSR is defined as the commitment of a company to respect consumer rights and interests [24]. Consumers, like any stakeholder group, will primarily observe a firm's behavior toward them. When focusing on consumers, socially responsible firms should be capable of developing a distinctive market image to both attract and retain customers. Therefore, if a company can protect consumer rights or carefully check the origins of the products it sells, then we could say this company has consumer CSR.

Environmental CSR can be defined as a company's commitment to respecting and protecting the natural environment [24]. A company that is environmentally responsible will try to prevent pollution, reduce the environmental damage that their products may cause, and, in general, be sustainable in its operations $[25,26]$. Based on these arguments, the concept of CSR in the present research includes both consumer CSR and environmental CSR.

\subsection{Perceived Value of Sustainability}

The perceived value of sustainability regarding CSR has been revamped, with new practices whose central characteristics are the ability to save or make money, provide a novel consumer experience, brand commitment, reduce ecological and carbon footprints, and strengthen social ties [27]. This sense of the importance and urgency of sustainability is reflected in the increased attention from governance policy, literature, and business [28]; and it has become an increasingly important strategic concern for companies [29]. In their perception of sustainability, people are limiting their purchases and are changing their notion of ownership. According to [30], various motives have framed the sharing economy into sustainability, such as economic, environmental, and social motives. In the case of Airbnb Inc., they not only provide an affordable accommodation solution for the traveler, but they also offer a more authentic local experience for the leisure community. The authors [31,32] pointed out that participation in CSR is generally highly ecologically sustainable and sociable. Therefore, the perceived value of sustainability toward CSR issues may be a key factor in motivating people to participate in the sharing economy business. Therefore, it is hypothesized that:

Hypotheses 1 (H1). CSR positively influences perceived value of sustainability.

\subsection{Consumer-Company Identification (C-C Identification)}

Based on social identity theory and organizational identification theory, Bhattacharya, C.B. and Sen, S. [7] expanded the concept of identification [33] and designed a conceptual framework for C-C identification. Regarding the relationship between CSR and C-C identification, Sen, S. [34] suggested that a firm's CSR activities can help the company build meaningful connections with consumers, as CSR actions transfer a firm's mission into its soul or character, which affects consumers' emotions as they relate to the company. Previous studies have also proved that CSR beliefs could become a key driver of C-C identification $[10,14]$.

CSR is about doing good deeds without expecting anything in return; consumers may use their associations with CSR companies to define themselves and maintain a positive inner and social self-image as they consume products [35].

Research by [36] suggested that the $\mathrm{C}-\mathrm{C}$ relationship strengthens as the consumer associates more strongly with a company's CSR initiatives. As a result, a corporation's socially responsible behavior positively affects $C-C$ identification $[10,12,14,37,38]$.

Drawing on the previous discussion, there appears to be no doubt that the relationship between CSR and $\mathrm{C}-\mathrm{C}$ identification has a positive effect on each. Thus, the following hypothesis (H2) is proposed:

Hypotheses 2 (H2). CSR positively influences consumer-company identification.

\subsection{Social Capital}

A proceeding of a Harvard Kennedy School seminar described social capital as "social networks that have value". Social capital theory is concerned with the nature, structure, and resources embedded 
in a person's network of relationships [39,40], and social capital or social currency is the extent to which people share the value of or information about a brand or business model as part of their everyday social life online in particular communities.

An environment of trust and caring develops social capital and ensures free communication in all directions, which means that companies participating in/holding CSR events and which have sustainable values can create social capital. The latter outcome can be best achieved when social capital formation is managed from a holistic perspective of sustainability principles, values, and concepts. Social capital [41] can be thought of as a durable web of social dyadic and group relationships. Social capital is defined as "the sum of the resource, actual or virtual, that accrue to an individual or group by virtue of possessing a durable network of more or less institutionalized relationships of mutual acquaintance and recognition" [42]. Therefore, the authors propose Hypotheses 3 and 4 and assume that the perceived value of sustainability and $\mathrm{C}-\mathrm{C}$ identification positively influences social capital:

Hypotheses 3 (H3). Perceived value of sustainability positively influences social capital.

Hypotheses 4 (H4). Consumer-company identification positively influences social capital.

\subsection{Consumer Citizenship Behavior}

A consumer citizen is an individual who makes choices based on economic, social, ethical, and ecological considerations. Consumer citizenship actively contributes to the maintenance of just and sustainable development by caring and acting responsibly on family, community, and global levels. One study [43] mentioned that " $88 \%$ of consumers said they were more likely to buy from a company that supports and engages in activities to improve society (CSR activities)". Mazzi et al. [44] mentioned that the relationship between environmental performance (EP) and business performance (BP) is even more relevant from the firms' perspective, since companies have great interest in learning about the economic benefits of environmental responsibility. In the case of Airbnb Inc., the hosts and guests both benefit by increasingly participating in the social platforms of the sharing economy through collaborative consumption and even CSR events [45].

Consumer citizenship behavior includes voluntary customer behaviors that benefit the company and go beyond simple customer role expectations [46]. Customers perform citizenship behavior at their sole discretion [47,48], and consumer citizenship behavior provides extraordinary value to a company. According to the concept of organizational citizenship behavior [49], consumers are more likely to express their support for an organization, such as a brand community, by undertaking behaviors like purchasing products from that company [15], making recommendations to others, and engaging in positive word-of-mouth (WOM) $[47,50]$. Thus, some research has suggested that consumer citizenship is exhibited through a variety of behaviors, including positive WOM communication, constructive involvement in suggesting service improvements, and other polite and courteous behaviors [47,51].

The formulation of social capital has been studied at the micro-level and social currency was identified as the social system reflecting an individual actor's intention and vision [52]. In addition, that author also explained how social currency is a critical determinant in the maximization of human behavior potential. A survey report on American families [20] found that a third of participants consider a company's commitment to social responsibility in their purchase decision process. When it comes to the environment and sustainability, the study found that the "percentage of consumers who are willing to pay more for sustainable brands that showed commitment to social and environmental values went up from $55 \%$ to $66 \%$ between 2014 and 2015 ", and that " $73 \%$ of the younger generations are more likely to pay more for sustainability". Similarly, sustainable purchasing behavior and subjective norms are positively correlated if the perceived subjective norms correspond with one's personal norms [53]. In other words, doing good is doing well with consumers.

As such, when a company engages in a CSR program, consumers might recognize that company as being altruistic, which could lead to more favorable evaluations of that company [54] and a gradual consumer identification with that company's values. Hence, consumers are more likely to engage 
in reciprocation through consumer citizenship behavior that may benefit that specific company [48]. Therefore, the following hypotheses are proposed:

Hypotheses 5 (H5). Perceived value of sustainability positively influences consumer citizenship behavior.

Hypotheses 6 (H6). Consumer-company identification positively influences consumer citizenship behavior.

Hypotheses 7 (H7). Social capital positively influences consumer citizenship behavior.

The hypotheses above are summarized in Table 1.

Table 1. Summary of research hypotheses.

\begin{tabular}{cc}
\hline Hypothesis & Describe Hypothesis \\
\hline H1 & H1: CSR positively influences Perceived Value of Sustainability \\
H2 & H2: CSR positively influences Customer Citizenship Identification \\
H3 & Perceived value of Sustainability positively influences Social Capital \\
H4 & Consumer Company Identification positively influences social capital \\
H5 & Perceived value of Sustainability positively influences Customer Citizenship Behavior \\
H6 & Consumer Company Identification positively influences Customer Citizenship Behavior \\
H7 & Social Capital positively influences Customer Citizenship Behavior \\
\hline
\end{tabular}

Note: The conceptual model that integrates all these hypothesized relationships is presented in Figure 1 in the next section.

\section{Research Method}

\subsection{Research Framework and Hypotheses}

Based on the literature survey above, the conceptual framework shown in Figure 1 below was constructed as follows: (1) The independent variable is CSR; and (2) The dependent variables are perceived value of sustainability (PVOS), C-C identification, social capital (SC), and consumer citizenship behavior (CCB) in the context of a sharing economy business. In particular, this research measures: (1) the extent to which the CSR concepts of a sharing economy business (namely, Airbnb) affect its users' perceived value of sustainability and the attitude towards experiencing C-C identification; and (2) whether the perceived value of sustainability and the feedback provided by C-C identification positively affects social capital and consumer citizenship behavior.

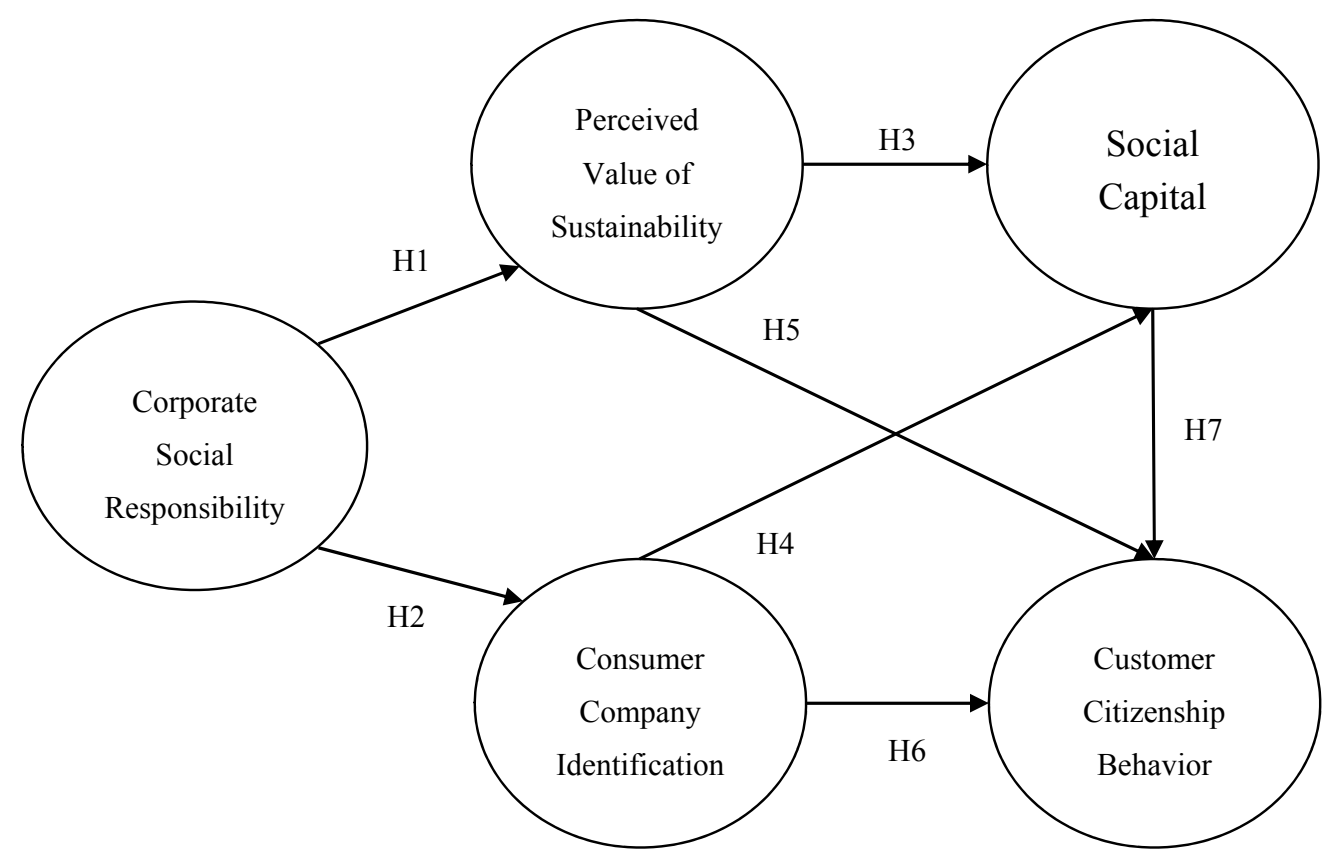

Figure 1. The research framework. 
This research applied a deductive approach in operationalizing the conceptual model by deriving measurement items from the literature [55]. This study presents the details of processes and findings resulting from the research framework in the context of the sharing economy and CSR, specifically as regards the company Airbnb. According to this theoretical framework and the purpose of this study, seven hypotheses were developed to answer the research questions.

\subsection{Data Collection and Sampling}

SEM was regarded as an appropriate technique for data analysis in this study. In order to obtain reliable results using SEM, [56] recommend that the number of samples should be at least 100, and that the number of measurements for each facet of the problem be at least three questions, and that the most appropriate number of samples should be between 300 and 500 participants. Based on those recommendations, this study has a total of 445 respondents.

\subsection{Research Method and Design}

In order to test the hypotheses, the survey questionnaires were distributed to respondents through online social networks, email, and other online communication platforms over a one-month period. To capture responses from adult travelers, the questionnaires, which briefly summarized the research topic and core case and explained the purpose of the research, took about $15 \mathrm{~min}$ to complete.

The survey questionnaire was developed by adapting measurements from a variety of academic studies; and the questionnaire's purpose was to identify factors, such as the perceived value of sustainability, $\mathrm{C}-\mathrm{C}$ identification, and social capital that accumulates from joining the sharing economy business, that affect consumer citizenship behavior such as purchasing or participating in a company that operates with CSR concepts. The questionnaire contained 27 questions. The first section, comprising six questions, dealt with CSR ideas regarding the perception of sustainability, in line with the concept adapted from [24]. Section 2 of the survey contained five questions about the participants' perceived value of sustainability, as proposed by [57]. Section 3 contained six questions related to $\mathrm{C}-\mathrm{C}$ identification, as adapted from [58] in the context of the sharing economy business Airbnb. Section 4 contained five questions about the awareness of social capital, a concept proposed by $[59,60]$. Five additional questions in the survey related to consumer citizenship behavior as it pertains to participating in a sharing economy business that holds CSR values and that are also mentioned in [61,62]. All items used to assess the constructs employed a 5-point Likert scale [63], from strongly disagree (1) to strongly agree (5). The items for each construct and their measurement scales are presented in Section 4.

\section{Results and Discussion}

\subsection{Demographic Profile of Respondents}

In this research, 445 valid responses were included for hypothesis testing. The demographic characteristics of respondents are listed in Table 2 below. In summary, the majority of respondents were female (51\%), 39.3\% were between the ages of 31 and 45 years old, $47.9 \%$ had a master's degree, and $42.2 \%$ of the respondents had a monthly income between $\$ 2001$ to $\$ 3000$ USD.

Table 2. Demographic characteristics of respondents.

\begin{tabular}{cccc}
\hline & Characteristics & $\mathbf{N}$ & $\%$ \\
\hline \multirow{2}{*}{ Gender } & Male & 218 & $49 \%$ \\
& Female & 227 & $51 \%$ \\
\hline \multirow{2}{*}{ Age } & $18-30$ years & 98 & $27.4 \%$ \\
& 31-45 years & 175 & $39.3 \%$ \\
& $46-60$ years & 122 & $22 \%$ \\
& 61 years and above & 50 & $11.2 \%$ \\
\hline
\end{tabular}


Table 2. Cont

\begin{tabular}{cccc}
\hline & Characteristics & N & $\%$ \\
\hline \multirow{3}{*}{ Education } & High School and below & 19 & $4.3 \%$ \\
& College or University degree & 171 & $38.4 \%$ \\
& Master Degree & 213 & $47.9 \%$ \\
& Doctoral Degree & 42 & $9.4 \%$ \\
\hline \multirow{5}{*}{ Monthly Income (USD) } & Under 1000 USD & 57 & $12.8 \%$ \\
& $1001-2000$ USD & 69 & $15.5 \%$ \\
& 2001-3000 USD & 188 & $42.2 \%$ \\
& 3000-4000 USD & 112 & $25.2 \%$ \\
& 4000 USD and above & 19 & $4.3 \%$ \\
\hline
\end{tabular}

\subsection{Measurement Model}

Before testing the hypotheses, the authors checked the model fit indexes. For this step, all the fit indexes for the structural model indicated an acceptable fit $\left(\chi^{2}\right.$ test statistics $/ \mathrm{df}=2.95 ; \mathrm{GFI}=0.93$; $\mathrm{AGFI}=0.90 ; \mathrm{CFI}=0.97 ; \mathrm{NFI}=0.95 ; \mathrm{RMSEA}=0.07$ ). The data indicated that the researchers could move on to the last analysis. Based on the results of the SEM, the proposed hypotheses were analyzed. The result of the measurements from the model-fit-structural model are shown in Table 3.

Table 3. Measurements of the model-fit-structural model.

\begin{tabular}{ccc}
\hline Goodness of Fit Measures & Recommendation Value & Structural Model (Result) \\
\hline$\chi^{2}$ test statistics / df & $<3$ & 2.95 \\
GFI (goodness-of-fit index) & $>0.90$ & 0.93 \\
AGFI (adjusted goodness-of-fit index) & $>0.90$ & 0.90 \\
CFI (comparative fit index) & $>0.90$ & 0.97 \\
NFI (normed fit index) & $>0.90$ & 0.95 \\
RMSEA (root mean square error of approximation) & $<0.08$ & 0.07 \\
\hline
\end{tabular}

Sources: [61].

Five model fit indices were consulted to test the adequacy of the measurement model produced in the main study. Following [64], using a two-step approach for assessing the structural model, the authors first assessed reliability and convergent validity, as shown in Table 4, and then assessed discriminant validity, as illustrated in Table 5.

Table 4. Constructs and measurement items.

\begin{tabular}{|c|c|c|c|c|c|}
\hline Construct & Measurement Items & Loading & $\alpha$ & CR & AVE \\
\hline \multirow{3}{*}{$\begin{array}{l}\text { Corporate Social } \\
\text { Responsibility (CSR) [24] }\end{array}$} & 1. Airbnb services care for the natural environment & 0.87 & \multirow{3}{*}{0.88} & \multirow{3}{*}{0.88} & \multirow{3}{*}{0.72} \\
\hline & 2. Airbnb services are attentive to recycling of materials & 0.89 & & & \\
\hline & 3. Airbnb services protect consumers' rights & 0.78 & & & \\
\hline \multirow{3}{*}{$\begin{array}{l}\text { Perceived Value of } \\
\text { Sustainability (PVOS) [57] }\end{array}$} & $\begin{array}{l}\text { 4. I believe that the concepts of Sharing economy and CSR of Airbnb help } \\
\text { save natural resources. }\end{array}$ & 0.84 & \multirow{3}{*}{0.89} & \multirow{3}{*}{0.89} & \multirow{3}{*}{0.73} \\
\hline & 5. Sharing economy and CSR are a sustainable mode of consumption. & 0.89 & & & \\
\hline & 6. Sharing economy and CSR are ecological. & 0.83 & & & \\
\hline \multirow{3}{*}{$\begin{array}{l}\text { Consumer Company } \\
\text { Identification (CCID) [58] }\end{array}$} & 7. When someone criticizes Airbnb Inc., it feels like a personal insult & 0.78 & \multirow{3}{*}{0.87} & \multirow{3}{*}{0.87} & \multirow{3}{*}{0.70} \\
\hline & 8. My friends and I advocate Airbnb's sustainability and CSR concept. & 0.86 & & & \\
\hline & $\begin{array}{l}\text { 9. When someone compliments Airbnb Inc., it feels like a personal } \\
\text { compliment }\end{array}$ & 0.86 & & & \\
\hline \multirow{3}{*}{ Social Capital (SC) $[59,60]$} & 10. I believe Airbnb Inc. creates high levels of social identity and values. & 0.85 & \multirow{3}{*}{0.88} & \multirow{3}{*}{0.88} & \multirow{3}{*}{0.72} \\
\hline & $\begin{array}{l}\text { 11. The sharing economy business such as Airbnb creates very tight } \\
\text { affiliation between Friends/families. }\end{array}$ & 0.87 & & & \\
\hline & $\begin{array}{l}\text { 12. We have lots of communication about the travel accommodation in } \\
\text { the Airbnb official webpage and its virtual community, such as Facebook } \\
\text { fan page }\end{array}$ & 0.82 & & & \\
\hline \multirow{3}{*}{$\begin{array}{l}\text { Customer Citizenship } \\
\text { Behavior (CCB) }[61,62]\end{array}$} & 13. I will keep buying the products/services of Airbnb Inc. & 0.86 & \multirow{3}{*}{0.87} & \multirow{3}{*}{0.87} & \multirow{3}{*}{0.70} \\
\hline & 14. I will recommend Airbnb Inc. services to my relatives and friends & 0.90 & & & \\
\hline & 15. I encourage friends to go to experience Airbnb Inc. service & 0.74 & & & \\
\hline
\end{tabular}


Table 5. Correlations of latent variables and average variance extracted (AVES).

\begin{tabular}{cccccccc}
\hline & Mean & SD & CSR & PVOS & CCID & SC & CCB \\
\hline CSR & 3.94 & 0.61 & 0.84 & & & & \\
PVOS & 3.87 & 0.66 & $0.64^{* *}$ & 0.85 & & & \\
CCID & 3.91 & 0.65 & $0.70^{* *}$ & $0.59^{* *}$ & 0.84 & & \\
SC & 3.78 & 0.58 & $0.71^{* *}$ & $0.70^{* *}$ & $0.73^{* *}$ & 0.85 & \\
CCB & 3.73 & 0.68 & $0.50^{* *}$ & $0.53^{* *}$ & $0.54^{* *}$ & $0.69^{* *}$ & 0.84 \\
\hline
\end{tabular}

Note: Diagonals represent the square root of the average variance extracted, while the other entries represent the correlations. ${ }^{* *} p<0.01 ;{ }^{* * *} p<0.001$.

Judging from the proportion of the substantive agreement and the substantive-validity coefficient as suggested by [64], a minimum of three measurement items were kept for each of the five constructs. To examine reliability, as shown in Table 4, Cronbach's alpha revealed that all the constructs showed a value above 0.7 [65]. To test for convergent validity, the authors examined composite reliability (CR), factor loading, and average variance extracted (AVE). The CR scores of all constructs were above 0.70 [66]; the AVE scores are above the cutoff point of 0.50 , indicating convergent validity $[67,68]$. The Cronbach's alpha values were 0.74 to 0.90 , both higher than 0.7. Moreover, the square roots of the AVE were greater than any correlations between the associated constructs and other constructs, suggesting discriminant validity [66]. Discriminant validity is further discussed in Section 4.3.

\subsection{Discriminant Validity}

To examine the discriminant validity of the constructs, this study used the criterion from [68], whereby the average variance shared between each construct and its measures should be greater than the variance shared between the construct and other constructs. In this study, the square root of AVE for each construct was greater than the correlations of the construct with other constructs. As shown in Table 5, the correlations for each construct were less than the square root of the AVE for the indicators measuring that construct, indicating adequate discriminant validity.

\subsection{Structural Model Testing}

The framework model for this research was examined using AMOS 19. Figure 2 shows the results of the structural equation model, specifically that CSR has a significant and positive influence on both the perceived value of sustainability $(\mathrm{H} 1, \beta=0.727, p<0.001)$ and $\mathrm{C}-\mathrm{C}$ identification $(\mathrm{H} 2, \beta=0.802$, $p<0.01$ ). Therefore, $\mathrm{H} 1, \mathrm{H} 2$ were both supported. The model predicted the path from perceived value of sustainability to social capital $(\mathrm{H} 3, \beta=0.447, p<0.001)$, and showed that there was a significant effect, however consumer citizenship behavior $(\mathrm{H} 5, \beta=0.040, p>0.05)$ was not accepted.

The results support hypothesis H3 but do not support H5. Furthermore, $\mathrm{C}-\mathrm{C}$ identification has a significant and positive influence on social capital $(\mathrm{H} 4, \beta=0.556, p<0.001)$ and consumer citizenship behavior (H6, $\beta=0.171, p>0.05)$. Therefore, $\mathrm{H} 4$ was supported but $\mathrm{H} 6$ was not. Social capital has a significant and positive influence on consumer citizenship behavior $(\mathrm{H} 7, \beta=0.937, p<0.01)$. Therefore, H7 is supported.

Among the seven hypotheses, five were supported: (1) Corporate social responsibility to perceived value of sustainability; (2) Corporate social responsibility to C-C identification; (3) Perceived value of sustainability to social capital; (4) C-C identification to social capital; and (5) Social capital to consumer citizenship behavior. The resulting numbers are shown in Figure 2 and Table 6. 


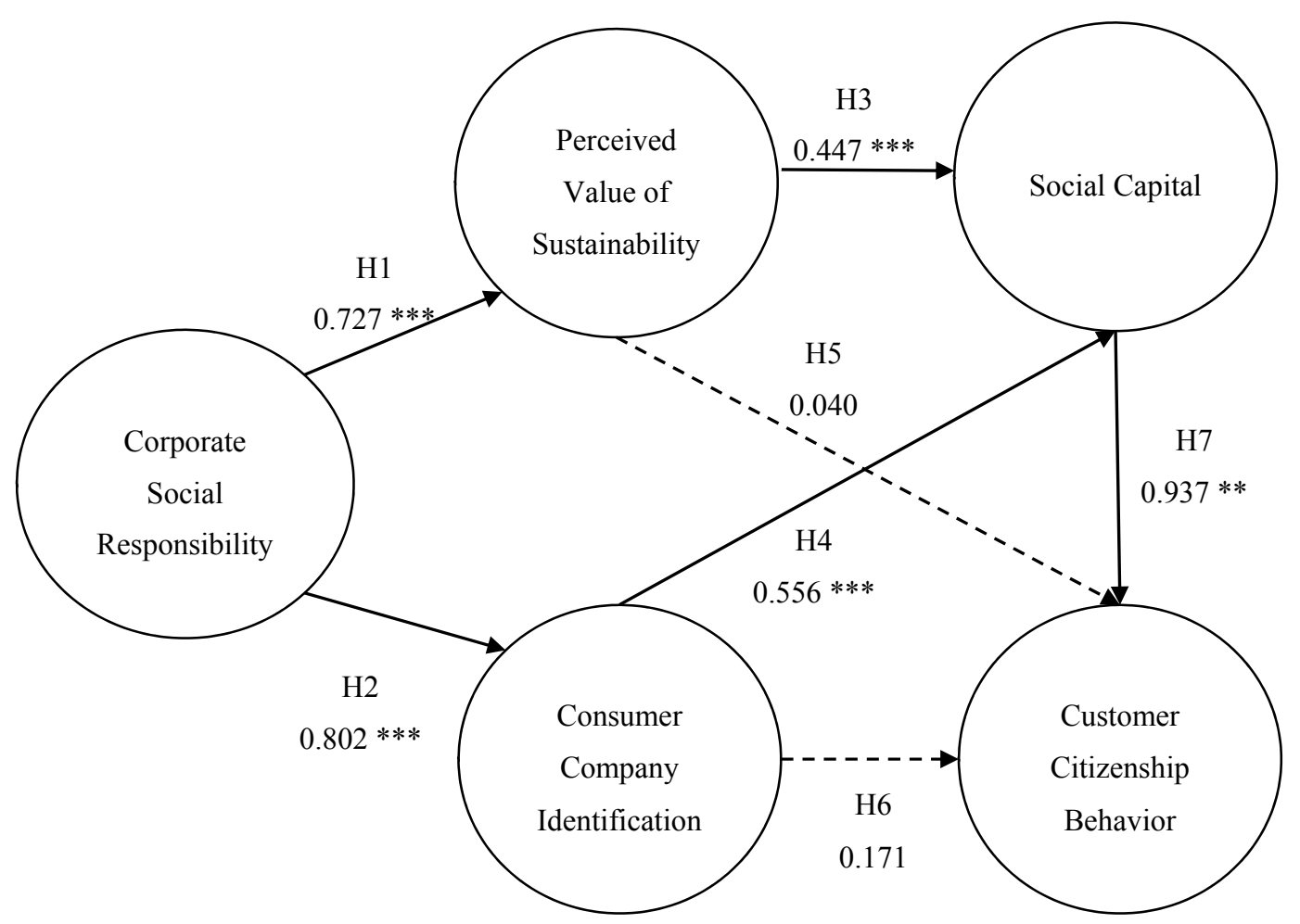

Figure 2. Results of the testing model. Note: ${ }^{* *} p<0.01$.; ${ }^{* *} p<0.001$.

Table 6. Results of testing.

\begin{tabular}{ccccc}
\hline Hypothesis & Path Coefficient & $\boldsymbol{t}$-Value & Supported \\
\hline H1 & CSR $\rightarrow$ PVOS & $0.727^{* * *}$ & 13.689 & Yes \\
H2 & CSR $\rightarrow$ CCID & $0.802^{* * *}$ & 15.333 & Yes \\
H3 & PVOS $\rightarrow$ SC & $0.447^{* * *}$ & 10.012 & Yes \\
H4 & CCID $\rightarrow$ SC & $0.556^{* * *}$ & 11.990 & Yes \\
H5 & PVOS $\rightarrow$ CCB & 0.040 & 0.524 & No \\
H6 & CCID $\rightarrow$ CCB & 0.171 & 1.880 & No \\
H7 & SC $\rightarrow$ CCB & $0.937^{* *}$ & 6.998 & Yes \\
\hline \multicolumn{5}{c}{ Note: $^{* *} p<0.01^{* * * *} p<0.001}$.
\end{tabular}

\subsection{Significant Findings}

Despite the growing interest among marketers in the use of social media platforms to increase connectivity between their brands and consumers [69], very few studies have discussed how marketers can use the CSR concepts with the perceived value of sustainability and the relationship of $\mathrm{C}-\mathrm{C}$ identification as a strategy to affect social capital and consumer citizenship behavior.

This study measured the power of CSR concepts/activities, the perceived value of sustainability, and $\mathrm{C}-\mathrm{C}$ identification in individuals' accumulation of social capital, and investigated the meditation relationship between these factors. In the language of path analysis, mediation corresponds to an indirect effect of an independent variable on a dependent variable that passes through one or more mediator variables [70]. As the findings indicate, a company's participation in CSR concepts affects the value of sustainability ( $\mathrm{H} 1)$ and $\mathrm{C}-\mathrm{C}$ identification $(\mathrm{H} 2)$ as perceived by consumers, both significant in the context of the sharing economy business model; however, such participation did not have a direct association with consumer citizenship behavior. This finding is worth further investigation, however, as the results showed that CSR does have a positive effect through perceived value of sustainability and social capital (path coefficient $\mathrm{H} 1 \times \mathrm{H} 3 \times \mathrm{H} 7=0.305$ ) to consumer citizenship 
behavior. Therefore, potentially, social capital fully mediates the path between perceived value of sustainability and consumer citizenship behavior.

On the other hand, the path of the CSR factor through C-C identification to a consumer's commitment to a company and the accumulation of social capital toward its consumer citizenship behavior $(\mathrm{H} 2 \times \mathrm{H} 4 \times \mathrm{H} 7=0.418)$ also demonstrated a significant and fully meditational effect in the context of the sharing economy business and CSR activities. From the discussions above, the authors drew the conclusion that sharing economy businesses that are involved in CSR activities, in this case Airbnb, can be operated via constructs like perceived value of sustainability, C-C identification, and the critical factor of social capital to positively influence consumer citizenship behavior. According to [71], the results determine the mediated effects listed below, as shown in Table 7 , and the mediated effect of paths through $(\mathrm{H} 2 \times \mathrm{H} 4 \times \mathrm{H} 7)>(\mathrm{H} 1 \times \mathrm{H} 3 \times \mathrm{H} 7)$.

Table 7. Mediated effects.

\begin{tabular}{|c|c|c|c|c|}
\hline \multicolumn{2}{|c|}{ Combined Hypotheses and Constructs } & Direct Effects & \multirow{2}{*}{$\begin{array}{c}\text { Mediated Effects } \\
0.305\end{array}$} & \multirow{2}{*}{$\begin{array}{c}\begin{array}{c}\text { Significantly Affect } \\
\text { Behavior Intention }\end{array} \\
\text { Yes }\end{array}$} \\
\hline $\begin{array}{c}\mathrm{H} 1 \times \mathrm{H} 3 \times \mathrm{H} 7 \\
\mathrm{H} 1 \times \mathrm{H} 5\end{array}$ & $\begin{array}{c}\mathrm{CSR} \rightarrow \mathrm{PVOS} \rightarrow \mathrm{SC} \rightarrow \mathrm{CCB} \\
\mathrm{CSR} \rightarrow \mathrm{PVOS} \rightarrow \mathrm{CCB}\end{array}$ & & & \\
\hline $\mathrm{H} 2 \times \mathrm{H} 4 \times \mathrm{H} 7$ & $\mathrm{CSR} \rightarrow \mathrm{CCI} \rightarrow \mathrm{SC} \rightarrow \mathrm{CCB}$ & & 0.418 & Yes \\
\hline $\mathrm{H} 2 \times \mathrm{H} 6$ & $\mathrm{CSR} \rightarrow \mathrm{CCI} \rightarrow \mathrm{CCB}$ & & & No \\
\hline
\end{tabular}

Source: this research.

In sum, among the seven presented and tested hypotheses, five were supported, while $\mathrm{H} 5$ and $\mathrm{H} 6$ were not supported. The results produced notable findings that are discussed in the following section.

\section{Conclusions}

Today, the sharing economy business model and CSR activities force people to push the boundaries of their lives and turns consumers into active members of varied communities. In this study, the authors proposed that social capital within the environment of CSR concepts/activities in the sharing economy may be a key factor influencing consumer citizenship behavior toward a company. Marketing managers could propose and operate effective marketing strategies based on the perceived value of sustainability (H1) and C-C identification (H2) by using consumer perceptions of sustainability and C-C identification within an organization. Such marketing actions should also be used to build social identity (social capital) toward consumers (H3, H4). However, in this study using Airbnb as the case company, the perceived value of sustainability and C-C identification did not directly influence consumer citizenship behavior (H5, H6). It is worth pointing out that social capital directly positively influences consumer citizenship behavior (H7), and the results showed that social capital is a mediating variable in this research. It explains the relationship between the dependent variable (perceived value of sustainability, $\mathrm{C}-\mathrm{C}$ identification) and independent variable (consumer citizenship behavior). Therefore, social capital is crucial in the context of entrepreneurial sustainability in the marketing field.

\subsection{Contribution}

This study explores a new approach that can help marketing managers implement marketing strategies that increase consumer citizenship behavior to encourage their participation in a sharing economy business. Airbnb connects travelers seeking authentic experiences with hosts offering unique and inspiring spaces around the world [72]. In the context of this study, the perceived value of sustainability, C-C identification, and social capital were considered the online and offline marketing strategies that change online fans into offline real customers.

In previous studies, CSR and its impact on consumer citizenship behavioral intentions were studied with a focus on examining CSR as a whole. By examining two specific concepts of CSR, it is undoubtedly true that CSR positively affects both perceived value of sustainability $[37,73]$ and 
C-C identification [10,12-14,38]. Moreover, this study confirmed the importance of social capital, as in [74-76]. The results obtained from this study offer important contributions and have important implications for both marketing academia and practitioners.

The significant contributions of this research are: (1) CSR may be the key to influencing consumer citizenship behavior; however, this construct needs to operate with other sub-factors, such as perceived value of sustainability, C-C identification, and social capital; (2) CSR concepts were translated into consumer citizenship behavior through perceived value of sustainability and C-C identification, both of which must go through the operation of social capital; (3) Through social capital, CSR with a sustainability perception can effectively and directly influence consumer citizenship behavior; and (4) Through social capital, a company that runs CSR with C-C identification can effectively and directly influence consumer citizenship behavior. The impact of $\mathrm{C}-\mathrm{C}$ identification is higher than the perceived value of sustainability, which means that the marketing strategy for a company using CSR concepts/activities and that operates with C-C identification and social capital could be more powerful in their marketing strategies than a company that operates with perceived value of sustainability and social capital; and (5) The results indicated that the perceived value of sustainability significantly predicted the accumulation of social capital, and social capital can directly and significantly affect consumer citizenship behaviors.

The perceived value of sustainability and $\mathrm{C}-\mathrm{C}$ identification alone each did not have a mediated effect toward consumer citizenship behavior; therefore, marketing managers should bring social-capital-related activities in line with both factors simultaneously to influence consumer citizenship behavior.

Social capital was proven in this research to be the key driver of citizenship behavior intention to participate in Airbnb services/products, which refers to a consumer's general perception and future intention about sharing economy businesses and CSR activities. Many studies have discussed the relationship between CSR and consumers' behavior intention [30,77]. However, few studies have discussed the comprehensiveness of a marketing strategy from a theoretical basis and in terms of entrepreneurship marketing. Therefore, the present study fills important research gaps and represents a crucial advancement in practice.

\subsection{Theoretical and Managerial Implications}

The findings of this study have practical implications for business practices. First, it is clear that companies holding CSR concepts/activities have the potential to exert a significant and positive influence on consumer attitudes and evaluations (perceived value of sustainability and C-C identification). From a managerial point of view, however, these findings should be considered as overall supportive of those companies that have chosen to engage in CSR. In reality, CSR has been considered as a means to develop public relations, improve company image, and increase sales. However, the idea and procedures of CSR are not easy to manage and must be carefully implemented to avoid likely consumer skepticism. Managers should make every effort to accrue knowledge of the various effects that CSR may have on consumer evaluations. This finding also suggests new insights for practitioners to enable them to create and maintain a state of closeness with a high level of social capital between a CSR company and consumer behaviors through C-C identification, which was shown to be stronger than the perceived value of sustainability. This means that when consumers evaluate a CSR company, it is important to establish a high level of social capital and C-C identification, e.g., good brand commitment to the company plays a more important role than the perceived value of sustainability does.

The results have theoretical and managerial implications for the marketing and management of the sharing economy business and CSR activities. From a theoretical perspective, the authors have shown how factors like CSR, perceived value of sustainability, C-C identification, social capital, and consumer citizenship behavior have been used to address different research issues in academic areas. In the present study, the authors used a sharing economy business (Airbnb) to analyze and confirm research 
hypotheses and research questions. The sharing economy implies collaborative consumption of physical, virtual, and intellectual goods [30]. It is a trend in consumer relationships that all sharing information is communicated via technology tools, such as social media and mobile technology, to create a sense of virtual community and to improve the level of social capital. As discussed above, social capital was shown to be a powerful positive influence on consumer citizenship behavior, which is consistent with [45], who explored social behavior of CSR along with technology that has created new customer experiences for not only the perception of sustainability but also C-C identification.

In prior research, the most common term used in addition to CSR is "corporate sustainability". Corporate sustainability focuses on long-run shareholder value by incorporating principles in nine areas: ethics, governance, transparency, business relationships, financial return, community involvement, product value, employment practices, and environmental protection [78]. Thus, the activities associated with corporate sustainability are very similar to those discussed in this research, especially in the perceived value of sustainability (product value/environmental protection) and C-C identification (business relationships/community involvement).

For this reason, the authors have proved those factors that may positively affect consumer citizenship behavior. The authors believe that marketers can develop strong citizenship behavior to participate in a sharing economy business that uses CSR activities by creating a good sense of $\mathrm{C}-\mathrm{C}$ identification and events that create a greater value of sustainability perception, and by accumulating a high level of social capital. The results of this innovative research model correspond with several other studies. Accordingly, many marketers rely on holding/participating in the CSR activities and creating a high perceived value of sustainability and $\mathrm{C}-\mathrm{C}$ identification along with accumulating social capital to generate future consumer citizenship behavior intentions. Marketers have realized that operating, accumulating, and obtaining social capital in the social media community are the most effective and significant mediators in influencing consumer behavior. Consequently, the authors can suggest that entrepreneurs/executives may believe that CSR affects the perception of sustainability, consumer-company identification and improve consumer citizenship behavior. Most importantly CSR activities focusing on sustainability issues and operate with social capital may lower costs and improve efficiencies as well. This finding could be viewed as a pioneering benchmark for further research.

\subsection{Limitations and Future Research}

In this research paper, the authors raised a novel concept of CSR activities with social capital theory. Certain limitations of this study should be addressed. When addressing these limitations, the authors also suggest directions for future research.

First, the CSR concept can always be examined as a whole, which is a limitation of this study. The authors proposed and verified the hypotheses that the greater the commitment of a company to respecting consumer rights and interests and the greater the commitment by a company to respect and protect the natural environment, the greater the level of $\mathrm{C}-\mathrm{C}$ identification. However, this is not easy to observe in a long research period. In future research, the needs of communities, local people, and the environment, which are a long-term goal for companies participating in CSR, could be considered and investigated.

Second, our sample comprised primarily young adults (around 30 years); hence, their responses may not be completely generalizable to the population at large.

Third, this study was conducted in Taiwan, thus restricting its findings to that culture. Current research has suggested that cognitive, emotional, and behavioral responses may vary across cultures [79]. Based on [80] cultural dimensions, the Taiwanese culture is known to be more collective than individualistic. Therefore, the effect of the customer citizenship behavior may be different in more individualistic cultures. Future studies should explore the role of perception and behavior in terms of consumer responses to CSR across a variety of cultures.

Finally, this study examined only one service industry. Future researchers should explore consumers' perceptions of CSR and value of sustainability in different industries. 
Acknowledgments: All authors thank the editors and reviewers for their valuable comments.

Author Contributions: All of the authors contributed significantly to the completion of this manuscript, conceiving and designing the research, writing and improving the paper. All authors have read and approved the manuscript.

Conflicts of Interest: The authors declare no conflict of interest.

\section{References}

1. Harrison, J.; Freeman, R. Stakeholders, social responsibility, and performance: Empirical evidence and theoretical perspectives. Acad. Manag. J. 1999, 42, 479-485. [CrossRef]

2. Lee, E.M.; Parl, S.Y.; Rapert, M.I.; Newman, C.L. Does perceived consumer fit matter in corporate social responsibility issues? J. Bus. Res. 2012, 65, 1558-1564. [CrossRef]

3. Waddock, S.; Smith, N. Corporate social responsibility audits: Doing well by doing good. Sloan Manag. Rev. 2000, 41, 75-83.

4. Carroll, A.B. The pyramid of corporate social responsibility: Toward the moral management of organizational Stakeholders. Bus. Horiz. 1991, 34, 39-48. [CrossRef]

5. Crowther, D. Corporate social reporting: Genuine action or window dressing? In Perspectives on Corporate Social Responsibility; Crowther, D., Rayman-Bacchus, L., Eds.; Ashgate Publishing: Aldershot, UK, 2004; pp. $140-160$.

6. Idowu, S.O.; Towler, B.A. A comparative study of the contents of corporate social responsibility reports of UK companies. Manag. Environ. Qual. Int. J. 2004, 15, 420-437. [CrossRef]

7. Bhattacharya, C.B.; Sen, S. Doing better at doing good: When, why, and how consumers respond to corporate social initiatives. Calif. Manag. Rev. 2004, 47, 9-24. [CrossRef]

8. Tian, Z.; Wang, R.; Yang, W. Consumer responses to corporate social responsibility in China. J. Bus. Ethics 2011, 101, 197-212. [CrossRef]

9. Ellen, P.S.; Webb, D.J.; Mohr, L.A. Building corporate associations: Consumer attributions for corporate socially responsible programs. Acad. Mark. Sci. 2006, 34, 147-157. [CrossRef]

10. Lichtenstein, D.R.; Drumwright, M.E.; Braig, B.M. The effects of corporate social responsibility on customer donations to corporate-supported nonprofits. J. Mark. 2004, 68, 16-32. [CrossRef]

11. Mohr, L.A.; Webb, D.J.; Harris, K.E. Do consumers expect companies to be socially responsible? The impact of corporate social responsibility on buying behavior. J. Consum. Aff. 2001, 35, 45-72. [CrossRef]

12. Sen, S.; Bhattacharya, C.B. Does doing good always lead to doing better? Consumer reactions to corporate social responsibility. J. Mark. Res. 2001, 38, 225-243. [CrossRef]

13. Bhattacharya, C.B.; Rao, H.; Glynn, M.A. Understanding the bond of identification: An investigation of its correlates among art museum members. J. Mark. 1995, 59, 45-57. [CrossRef]

14. Bhattacharya, C.B.; Sen, S. Consumer-company identification: A framework for understanding consumers' relationships with companies. J. Mark. 2003, 67, 76-88. [CrossRef]

15. Ahearne, M.; Bhattacharya, C.B.; Gruen, T. Antecedents and consequences of customer-company identification: Expanding the role of relationship marketing. J. Appl. Psychol. 2005, 90, 574-585. [CrossRef] [PubMed]

16. Berens, G.; van Riel, C.B.M.; van Bruggen, G.H. Corporate Associations and Consumer Product Responses: The Moderating Role of Corporate Brand Dominance. J. Mark. 2005, 69, 35-48. [CrossRef]

17. Madrigal, R. The role of corporate associations in new product evaluation. In Advances in Consumer Research; Hoch, S.J., Meyer, R.J., Eds.; Association for Consumer Research: Provo, UT, USA, 2000; pp. 80-86.

18. Cooper, E. Sharing Economy has Strong CSR Potential PBA. Pro Bono Australia. 2017. Available online: https:/ / probonoaustralia.com.au/news/2016/02/sharing-economy-has-strong-csr-potential/ (accessed on 3 July 2017).

19. Zervas, G.; Proserpio, D.; Byers, J.W. The Rise of the Sharing Economy: Estimating the Impact of Airbnb on the Hotel Industry. J. Mark. Res. 2016, 1-45. [CrossRef]

20. Zax, D. Airbnb Now Offers "Social Impact Experiences." How Much Good Will They Do? Fast Company, 2017. Available online: https://www.fastcompany.com/3065925/airbnb-now-offers-socialimpact-experiences-how-much-good-will-they-do (accessed on 3 July 2017). 
21. Carroll, A.B. A three-dimensional conceptual model of corporate performance. Acad. Manag. Rev. 1979, 4, 497-505.

22. Brahme, U. Sharing Economy, CSR and Sustainability: Making the Connection-I. 2017. Available online: https://www.linkedin.com/pulse/sharing-economy-csr-sustainability-making-connection-iunmesh-brahme (accessed on 7 July 2017).

23. Kotler, P. Marketing Management, 13th ed.; Prentice-Hall: Upper Saddle River, NJ, USA, 2008.

24. Perrini, F.; Castaldo, S.; Misani, N.; Tencati, A. The impact of corporate social responsibility associations on trust in organic products marketed by mainstream retailers: A study of Italian consumers. Bus. Strateg. Environ. 2010, 19, 512-526. [CrossRef]

25. Hart, S. A natural resource-based view of the firm. Acad. Manag. Rev. 1995, 20, 986-1014.

26. First, I.; Khetriwal, D.S. Exploring the relationship between environmental orientation and brand value: Is there fire or only smoke? Bus. Strateg. Environ. 2010, 19, 90-103. [CrossRef]

27. Schor, J.B.; Fitzmaurice, C.J. Collaborating and connecting: The emergence of the sharing economy. In Handbook of Research on Sustainable Consumption; Edward Elgar Publishing Ltd.: Cheltenham, UK, 2015; pp. 410-425.

28. Beske, P.; Johnson, M.; Schaltegger, S. 20 Years of Performance Measurement in Sustainable Supply Chain Management. What has been achieved? Supply Chain Manag. Int. J. 2015, 20, 664-680.

29. Tomšič, N.; Bojnec, Š.; Simčič, B. Corporate sustainability and economic performance in small and medium sized enterprises. J. Clean. Prod. 2015, 108, 603-612. [CrossRef]

30. Bachnik, K. Sustainable Consumption through the Sharing Economy. Prace Naukowe Uniwersytetu Ekonomicznego We Wrocławiu 2016. [CrossRef]

31. Prothero, A.; Dobscha, S.; Freung, J.; Kilbourne, W.E.; Luchs, M.G.; Qzanne, L.K.; Thogersen, J. Sustainable Consumption: Opportunities for Consumer Research and Public Policy. J. Public Policy Mark. 2011, 30, 31-38. [CrossRef]

32. Diehl, S.; Karmasin, M.; Mueller, B.; Terlutter, R.; Weder, F. Handbook of Integrated CSR Communication; Springer: Berlin, Germany, 2016.

33. Dutton, J.E.; Dukerich, J.M.; Harquail, C.V. Organizational images and member identification. Adm. Sci. Q. 1994, 39, 239-263. [CrossRef]

34. Sen, S. Building relationships through corporate social responsibility: The role of communication. In Proceedings of the 26th Advertising and Consumer Psychology (ACP) Conference, Santa Monica, CA, USA, 7-9 June 2007.

35. Vlachos, P.A.; Vrechopoulos, A.P. Consumer-retailer love and attachment: Antecedents and personality moderators. J. Retail. Consum. Serv. 2012, 19, 218-228. [CrossRef]

36. Marin, L.; Ruiz, S.; Rubio, A. The role of identity salience in the effects of corporate social responsibility on consumer behavior. J. Bus. Ethics 2009, 84, 65-78. [CrossRef]

37. Becker-Olsen, K.L.; Cudmore, B.A.; Hill, R.P. The impact of perceived corporate social responsibility on consumer behavior. J. Bus. Res. 2006, 59, 46-53. [CrossRef]

38. Du, S.; Bhattacharya, C.B.; Sen, S. Reaping relational reward from corporate social responsibility: The role of competitive positioning. Int. J. Res. Mark. 2007, 24, 224-241. [CrossRef]

39. Owlcation. Integrating Social Capital Theory and Social Exchange Theory. 2017. Available online: https: / / owlcation.com/social-sciences/Integrating-Social-Capital-and-Social-Exchange-Theory (accessed on 3 July 2017).

40. Seibert, S.E.; Kraimer, M.L.; Liden, R.C. A Social Capital Theory of Career Success. Acad. Manag. J. 2001, 44, 219-237. [CrossRef]

41. Linkov, I. Sustainable Cities and Military Installations; Springer: Berlin, Germany, 2013; p. 108.

42. Bourdieu, P. The Forms of Capital. In Education: Culture, Economy and Society; Halsey, A.H., Lauder, H., Brown, P., Stuart Wells, A., Eds.; Oxford University Press: Oxford, UK, 1997.

43. Bell, L. The Benefits of Corporate Social Responsibility 2017. Available online: http://www.simplycsr.co.uk/ the-benefits-of-csr.html (accessed on 3 July 2017).

44. Mazzi, A.; Toniolo, S.; Manzardo, A.; Ren, J.; Scipioni, A. Exploring the Direction on the Environmental and Business Performance Relationship at the Firm Level. Lessons from a Literature Review. Sustainability 2016, 8, 25. [CrossRef] 
45. Vivaldi Partners. Social Currency: Why Brands Need to Build and Nurture Social Currency. 2010. Available online: https: / /images.fastcompany.com/VivaldiPartners_SocialCurrency.pdf (accessed on 24 June 2017).

46. Gruen, T.W. The outcome set of relationship marketing in consumer markets. Int. Bus. Rev. 1995, 4, 447-469. [CrossRef]

47. Bettencourt, L.A. Customer voluntary performance: Customers as partners in service delivery. J. Retail. 1997, 73, 383-406. [CrossRef]

48. Groth, M. Customers as good soldiers: Examining citizenship behaviors in internet service deliveries. J. Manag. 2005, 31, 7-27. [CrossRef]

49. Bateman, T.S.; Organ, D.W. Job satisfaction and the good soldier: The relationship between affect and employee "citizenship". Acad. Manag. J. 1983, 26, 587-595. [CrossRef]

50. Anderson, E.W.; Fornell, C.F.; Mazvancheryl, S.K. Customer satisfaction and shareholder value. J. Mark. 2004, 68, 172-185. [CrossRef]

51. Rosenbaum, M.S.; Massiah, C.A. When customers receive support from other customers: Exploring the influence of intercustomer social support on customer voluntary performance. J. Serv. Res. 2007, 9, 257-270. [CrossRef]

52. Cofield, M. Building Social Capital in Multicultural Communities: The Dyadic Process and Related Social Outcomes of Executive Leaders. Ph.D. Thesis, St. John Fisher College, Ulster County, NY, USA, 2017.

53. Penz, E.; Hofmann, E.; Hartl, B. Fostering Sustainable Travel Behavior: Role of Sustainability Labels and Goal-Directed Behavior Regarding Touristic Services. Sustainability 2017, 9, 1056. [CrossRef]

54. Nan, X.; Heo, K. Consumer response to corporate social responsibility (CSR) initiatives. J. Advert. 2007, 36, 63-74. [CrossRef]

55. Hinkin, T.R. A Review of Scale Development Practices in the Study of Organizations. J. Manag. 1995, 21, 967-988. [CrossRef]

56. Hair, J.F.; Black, W.; Tatham, R.L.; Anderson, R.E. Multivariate Data Analysis, 5th ed.; Pearson Education (US): Upper Saddle River, NJ, USA, 1998.

57. Koh, J.; Kim, Y.G. Sense of Virtual Community: A Conceptual Framework and Empirical Validation. Int. J. Electron. Commer. 2003, 8, 75-93.

58. Mael, F.; Ashforth, B.E. Alumni and their Alma master: A partial test of the reformulated model of organizational identification. J. Organ. Behav. 1992, 13, 103-123. [CrossRef]

59. Berger, J. Contagious_-Why Things Catch on; Simon \& Schuster UK Ltd.: London, UK, 2013.

60. Zinnbauer, M.; Honer, T. How Brands Can Create Social Currency-A Framework for Managing Brands in a Network Era. Mark. Rev. St. Gallen 2011, 28, 50-55. [CrossRef]

61. Putrevu, S.; Lord, K.R. Comparative and noncomparative advertising: Attitudinal effects under cognitive and affective involvement conditions. J. Advert. 1994, 23, 77-90. [CrossRef]

62. Perez, A.; Salmones, M.M.G.; Bosque, I.R. The effect of corporate associations on consumer behavior. Eur. J. Mark. 2013, 47, 218-238. [CrossRef]

63. Likert, R. A technique for the measurement of attitudes. Arch. Psychol. 1932, 22, 1-55.

64. Anderson, J.C.; Gerbing, D.W. Structural Equation Modeling in Practice: A Review and Recommended Two-Step Approach. Psychol. Bull. 1988, 103, 411-423. [CrossRef]

65. Bagozzi, R.P.; Yi, Y. On the Evaluation of Structural Equation Models. J. Acad. Mark. Sci. 1988, 16, 74-94. [CrossRef]

66. Chin, W.W. The Partial Least Squares Approach for Structural Equation Modeling. In Modern Methods for Business Research; Marcoulides, G.A., Ed.; Lawrence Erlbaum: Hillsdale, NJ, USA, 1998; pp. 295-336.

67. Gefen, D. E-Commerce: The Role of Familiarity and Trust. Omega 2000, 28, 725-737. [CrossRef]

68. Fornell, C.R.; Larcker, F.F. Structural Equation Models with Unobservable Variables and Measurement Error. J. Mark. Res. 1981, 18, 39-51. [CrossRef]

69. Martin, K.; Todorov, I. How will digital platforms be harnessed in 2010, and how will they change the way people interact with brands? J. Interact. Advert. 2010, 10, 61-66. [CrossRef]

70. Edwards, J.R.; Lambert, L.S. Methods for integrating moderation and mediation: A general analytical framework using moderated path analysis. Psychol. Methods 2007, 12, 1-22. [CrossRef] [PubMed]

71. Baron, R.M.; Kenny, D.A. The Moderator-Mediator Variable Distinction in Social Psychological Research: Conceptual, Strategic, and Statistical Considerations. J. Personal. Soc. Psychol. 1986, 51, 1173-1182. [CrossRef] 
72. Airbnb Inc. Vacation Rentals, Homes, Experiences \& Places. Airbnb, 2017. Available online: https://www. airbnb.com/ (accessed on 13 February 2017).

73. McWilliams, A.; Siegel, D. Corporate social responsibility: A theory of the firm perspective. Acad. Manag. Rev. 2001, 26, 117-127.

74. Durlauf, S.N. On the empirics of social capital. Econ. J. 2002, 112, 459-479. [CrossRef]

75. Krishna, A. Moving from the Stock of Social Capital to the Flow of Benefits: The Role of Agency. World Dev. 2001, 29, 925-943. [CrossRef]

76. Adam, Frane, Borut Roncevic. Social Capital: Recent Debates and Research Trends. Soc. Sci. Inf. 2003, 42, 155-183.

77. Hamari, J.; Sjoklint, M.; Ukkonen, A. The Sharing Economy: Why People Participate in Collaborative Consumption. J. Assoc. Inf. Sci. Technol. 2016. [CrossRef]

78. Epstein, M.J. Making Sustainability Work; Best Practices in Managing and Measuring Corporate Social, Environmental, and Economic Impacts; Berrett-Koehler Publishers, Inc.: San Francisco, CA, USA, 2008.

79. Cole, P.M.; Bruschi, C.J.; Tamang, B.L. Cultural differences in children's emotional reactions to difficult situations. J. Child Dev. 2002, 73, 667-998. [CrossRef]

80. Hofstede, G. Culture's Consequences: Comparing Values, Behaviours, Institutions, and Organizations across Nations, 2nd ed.; Sage Publications: Thousand Oaks, CA, USA, 2001.

(c) 2017 by the authors. Licensee MDPI, Basel, Switzerland. This article is an open access article distributed under the terms and conditions of the Creative Commons Attribution (CC BY) license (http://creativecommons.org/licenses/by/4.0/). 